\title{
Dysfunction of the Cav2.I calcium channel in cerebellar ataxias
}

\author{
Sanjeev Rajakulendran, Stephanie Schorge, Dimitri M Kullmann and \\ Michael G Hanna*
}

\author{
Address: MRC Centre for Neuromuscular Diseases, Institute of Neurology, University College London, Queen Square, London WC1N 3BG, UK \\ *Corresponding author: Michael G Hanna (mhanna@ion.ucl.ac.uk) \\ FI000 Biology Reports 2010, 2:4 (doi:10.34I0/B2-4)
}

The electronic version of this article is the complete one and can be found at: http://fl 000.com/reports/biology/content/2/4

\begin{abstract}
Mutations in the CACNAIA gene are associated with episodic ataxia type 2 (EA2) and spinocerebellar ataxia type 6 (SCA6). CACNAIA encodes the $\alpha$-subunit of the P/Q-type calcium channel or Cav2.I, which is highly enriched in the cerebellum. It is one of the main channels linked to synaptic transmission throughout the human central nervous system. Here, we compare recent advances in the understanding of the genetic changes that underlie EA2 and SCA6 and what these new findings suggest about the mechanism of the disease.
\end{abstract}

\section{Introduction and context}

The $\mathrm{Ca}_{\mathrm{V}} 2.1$ calcium channel belongs to the superfamily of voltage-gated calcium channels. Its other designation, P/Q-type channel, refers to the cell types from which its constituent currents were originally isolated; the ' $\mathrm{P}$ ' stands for Purkinje and ' $\mathrm{Q}$ ' for granule cells of the cerebellum. The $\alpha$-subunit (Figure 1), encoded by CACNA1A, is associated with $\beta$ and $\alpha_{2} \delta$ auxiliary subunits that are thought to help in trafficking and anchoring the principal subunit to the cell membrane and also modulate the biophysical properties of the channel [1]. CACNA1A undergoes extensive alternative splicing resulting in $\mathrm{Ca}_{\mathrm{V}} 2.1$ channels with different properties [2-5]. These splice variants are differentially expressed throughout the central nervous system (CNS) and serve to adjust the biophysical parameters of the channel to its role in the various cell types.

The CACNA1A gene maps to chromosome 19p13 [6]. It is widely expressed throughout the CNS; however, in keeping with its original identification, this gene is expressed at a particularly high level in Purkinje and granule cells of the cerebellum. In much of the CNS, Cav2.1 channels are highly expressed pre-synaptically [7], where they couple calcium influx to vesicular exocytosis in fast neurotransmission. However, in Purkinje cells, $\mathrm{Ca}_{\mathrm{v}} 2.1$ channels serve an additional post-synaptic role in coordinating AMPA
( $\alpha$-amino-3-hydroxy-5-methyl-4-isoxazolepropionic acid) receptor activation with voltage-dependent calcium influx [8].

\section{Cay2.I and ataxia}

Dominant mutations in CACNA1A underlie at least three allelic diseases (Table 1). A large number of different point mutations (both nonsense and missense) have been shown to cause episodic ataxia type 2 (EA2), an acetazolamide-responsive disorder characterised by paroxysmal attacks of midline cerebellar disturbance manifesting as ataxia, imbalance, vomiting, oscillopsia, and interictal nystagmus [9-15]. Attacks last from hours to days, and triggers include stress and intercurrent infection. Several other EA syndromes have been described (reviewed in [16]); mutations in KCNA1 - the gene that encodes the $\mathrm{K}_{\mathrm{V}} 1.1$ potassium channel - underlie EA1, which is characterised by brief attacks of ataxia (lasting minutes) with interictal myokymia [17-20]. Interestingly, mutations in CACNB4, the gene that encodes one of the accessory $\beta$-subunits of $\mathrm{Ca}_{\mathrm{v}} 2.1$, also cause a form of EA [21].

EA2 mutations that result in premature stop codons are likely to generate a non-functional truncated peptide or trigger nonsense-mediated mRNA decay. Functional 
Figure I. Two-dimensional schematic of the $\alpha$-subunit of Cav2.I showing functionally important regions of the peptide

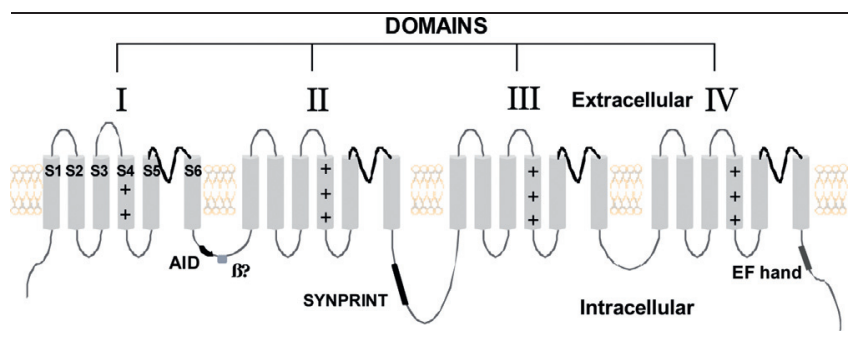

The subunit consists of four domains (I-IV), each containing six transmembrane segments (SI-S6). The S4 segment of each domain is lined with positively charged amino acids and acts as the voltage sensor. The S5-S6 interlinker forms the pore of the channel. The AID (alpha interaction domain) forms the binding pocket for the $\beta$-subunit of $\mathrm{Ca}_{\mathrm{v}} 2$.I. The SYNPRINT (synaptic protein interaction) region interacts with SNARE (SNAP (soluble N-ethylmaleimide-sensitive factor attachment protein) receptor) proteins such as syntaxin and SNAP-25, which are involved in synaptic transmission. Sites of $\mathrm{G}$-protein modulation via $\beta \gamma$-subunits are shown along with the 'EF' hand, which is considered to be involved in calcium-dependent facilitation.

characterisation of missense mutations in CACNA1A has demonstrated that mutations associated with EA2 result in a loss of $\mathrm{Ca}_{\mathrm{v}} 2.1$ channel function $[22,23]$. In addition, mutant subunits may disrupt the membrane trafficking of wild-type channels [24].

In contrast to EA2, spinocerebellar ataxia type 6 (SCA6) is a 'pure' progressive cerebellar syndrome that results, not from point mutations, but from an abnormal polyglutamine expansion in the channel's carboxylterminal domain, which is present in only certain splice isoforms of the CACNA1A mRNA [25]. Although changes in channel kinetics have been observed $[26,27]$, the pathogenic mechanism of SCA6 is poorly understood.

\section{Recent advances}

Direct sequencing of CACNA1A in a number of patients with clinical EA2 often fails to identify causative point mutations. However, the last year has witnessed a further step forward in understanding the genetic basis of EA2. Veneziano and colleagues [28] identified new $5^{\prime}$ and $3^{\prime}$ regions in the CACNA1A gene, including a gene promoter region and a new final exon 48, both of which harboured mutations in patients with EA. Furthermore, the mutation spectrum has expanded with the findings of large deletions and duplications in CACNA1A in affected individuals. Previously, nonsense and missense mutations accounted for most cases of EA2. Recently, methods such as MLPA (multiplex ligation-dependent probe amplification) and QMPSF (quantitative multiplex polymerase chain reaction of short fluorescent fragments) have demonstrated largescale CACNA1A gene rearrangements in patients with EA2 $[29,30]$. This finding is particularly important for those patients with clinical EA2 in whom sequencing of CACNA1A fails to identify a point mutation.

EA2 is an autosomal dominant disease, and because large deletions in CACNA1A are not likely to produce functional transcripts, it is likely that reduced channel density in the cerebellar circuit (possibly in Purkinje cells, where these channels have been shown to play a central role) is sufficient to cause episodes of ataxia. Moreover, the recent observation that nonsense mutations located within a well-known alternatively spliced exon (exon 37A) [31] can cause EA2 hints at a significant role of $\mathrm{Ca}_{\mathrm{V}} 2.1$ channels containing exon $37 \mathrm{~A}$ in the cerebellum and underpins the importance of calcium channel splicing in disease causation.

While increasing evidence points to a loss of robust $\mathrm{Ca}_{\mathrm{v}} 2.1$ expression in the cerebellum and haploinsufficency as the underlying mechanism of EA2, calcium channel

Table I. Mutations in CACNAIA underlie three allelic disorders: EA2, FHM and SCA6

\begin{tabular}{|c|c|c|c|c|c|}
\hline Disease & Core clinical features & Additional features & Inheritance & Mutations & $\begin{array}{l}\text { Functional } \\
\text { consequences }\end{array}$ \\
\hline $\begin{array}{l}\text { Episodic ataxia type } 2 \\
\text { (EA2) }\end{array}$ & $\begin{array}{l}\text { Attacks of ataxia, } \\
\text { vomiting, vertigo, } \\
\text { oscillopsia lasting } \\
\text { hours to days, and } \\
\text { interictal nystagmus }\end{array}$ & $\begin{array}{l}\text { Epilepsy, migraine, and } \\
\text { progressive cerebellar } \\
\text { syndrome }\end{array}$ & Autosomal dominant & $\begin{array}{l}\text { Nonsense and missense } \\
\text { mutations, small } \\
\text { deletions and insertions, } \\
\text { and large deletions }\end{array}$ & Loss of function \\
\hline $\begin{array}{l}\text { Familial hemiplegic } \\
\text { migraine type I } \\
\text { (FHMI) }\end{array}$ & $\begin{array}{l}\text { Rare subtype of MA: } \\
\text { attacks of hemiparesis } \\
\text { and hemisensory } \\
\text { disturbance lasting } \\
\text { hours to days }\end{array}$ & $\begin{array}{l}\text { Confusion, } \\
\text { encephalopathy, } \\
\text { ataxia, coma, } \\
\text { and seizures }\end{array}$ & Autosomal dominant & Missense mutations & Gain of function \\
\hline $\begin{array}{l}\text { Spinocerebellar ataxia } \\
\text { type } 6 \text { (SCA6) }\end{array}$ & $\begin{array}{l}\text { Late-onset progressive } \\
\text { cerebellar ataxia }\end{array}$ & & Autosomal dominant & $\begin{array}{l}\text { CAG expansion in } \\
\text { C-terminus }\end{array}$ & $\begin{array}{l}\text { Alteration of Cav2.I } \\
\text { channel kinetics; poly- } \\
\text { glutamine cytotoxicity? }\end{array}$ \\
\hline
\end{tabular}

The clinical and genetic features of each disorder are described. The effect of mutations on Cav2.I channel function is stated. MA, migraine with aura. 
dysfunction may not be at the root of SCA6. In support of this view, the expanded CAG repeat in the SCA6 knock-in mouse does not appear to affect $\mathrm{Ca}_{\mathrm{V}} 2.1$ function [32], indicating that the polyglutamine repeat itself may have a cytotoxic effect on the cell. It has recently been suggested that cerebellar dysfunction in a related polyglutamine repeat SCA (SCA2) may arise from aberrant activation of type 1 inositol 1,4,5-trisphosphate receptors (ITPRs) in Purkinje cells by the glutamine tracts themselves [33]. If activation of the ITPRs is the mechanism of polyglutamine repeat SCAs, then SCA6 may be a result of the relative abundance of $\mathrm{P} / \mathrm{Q}$ channels in Purkinje cells, rather than specific properties of the channels themselves.

\section{Future directions}

Despite advances in the genetic basis of EA2, many questions remain unanswered. From a mechanistic point of view, the paroxysmal nature of the neurological symptoms arising from mutations in CACNA1A remains a mystery. In addition, the physiological basis of how attacks are precipitated by stress or indeed relieved by acetazolamide still evades explanation. Answers to some of these questions may await the development of neuronal expression systems. This will allow the study of how genetic variation in the calcium channel gene affects the biophysical properties of $\mathrm{Ca}_{\mathrm{v}} 2.1$ in its physiological environment, especially with respect to synaptic transmission and dendritic depolarisation. A recent insight into this approach came from Heeroma and colleagues [34], who demonstrated that $K_{\mathrm{V}} 1.1$ mutations in EA1 exerted differential effects on excitation (rheobase) and synaptic transmission when expressed in neurons.

Although the polyglutamine tract in SCA6 is considered to confer a toxic gain of function, the exact roles of the alternative long- and short-splice variants of CACNA1A in Purkinje cells need to be defined. This may lead to a better understanding of how the expanded CAG repeat in SCA6 results in disease. An additional conundrum is why many spontaneous mutations in CACNA1A in mice result in a 3 $\mathrm{Hz}$ spike and wave epilepsy [35,36], whereas in humans, although a few mutations have been shown to co-segregate with EA2 and seizures [37,38], most deletions and truncations in the gene are associated with pure EA2 rather than absence epilepsy. Mutations of this gene appear to give two distinct phenotypes in humans and rodents. Understanding how these phenotypes are associated with different roles of $\mathrm{Ca}_{\mathrm{V}} 2.1$ channels in human and rodent tissues may be an important step in untangling the molecular pathogenesis of seizures and ataxia.

\section{Abbreviations}

CNS, central nervous system; EA, episodic ataxia; EA2, episodic ataxia type 2; ITPR, inositol 1,4,5-trisphosphate receptor; P/Q, Purkinje/granule; SCA, spinocerebellar ataxia; SCA6, spinocerebellar ataxia type 6 .

\section{Competing interests}

The authors declare that they have no competing interests.

\section{Acknowledgements}

The authors thank the Wellcome Trust, Medical Research Council (G0601943) and Action Research for financial support.

\section{References}

I. Catterall WA: Structure and regulation of voltage-gated $\mathrm{Ca2}^{+}$ channels. Annu Rev Cell Dev Biol 2000, 16:52I-55.

2. Kongsamut S, Lipscombe D, Tsien RW: The $\mathbf{N}$-type Ca channel in frog sympathetic neurons and its role in alpha-adrenergic modulation of transmitter release. Ann N Y Acad Sci 1989, 560:312-33.

3. Bourinet E, Soong TW, Sutton K, Slaymaker S, Mathews E, Monteil A Zamponi GW, Nargeot J, Snutch TP: Splicing of alpha I A subunit gene generates phenotypic variants of $\mathbf{P}$ - and Q-type calcium channels. Nat Neurosci 1999, 2:407-I5.

4. Tsunemi T, Saegusa H, Ishikawa K, Nagayama S, Murakoshi T, Mizusawa H, Tanabe T: Novel Cav2.I splice variants isolated from Purkinje cells do not generate P-type $\mathrm{Ca}^{+}$current. J Biol Chem 2002, 277:7214-2I.

5. Soong TW, DeMaria CD, Alvania RS, Zweifel LS, Liang MC, Mittman S, Agnew WS, Yue DT: Systematic identification of splice variants in human P/Q-type channel alphal(2.I) subunits: implications for current density and $\mathrm{Ca2}^{+}$-dependent inactivation. J Neurosci 2002, 22:10142-52.

6. Diriong S, Lory P, Williams ME, Ellis SB, Harpold MM, Taviaux S: Chromosomal localization of the human genes for alpha IA, alpha IB, and alpha IE voltage-dependent $\mathrm{Ca2}^{+}$channel subunits. Genomics 1995, 30:605-9.

7. Westenbroek RE, Sakurai T, Elliott EM, Hell JW, Starr TV, Snutch TP, Catterall WA: Immunochemical identification and subcellular distribution of the alpha IA subunits of brain calcium channels. J Neurosci 1995, I 5:6403-18.

8. Higley MJ, Sabatini BL: Calcium signaling in dendrites and spines: practical and functional considerations. Neuron 2008, 59:902-I3.

9. Jen JC, Baloh RW: Genetics of episodic ataxia. Adv Neurol 2002, 89:459-6I.

10. Jen J, Kim GW, Baloh RW: Clinical spectrum of episodic ataxia type 2. Neurology 2004, 62:17-22.

I I. Baloh RW, Yue Q, Furman JM, Nelson SF: Familial episodic ataxia: clinical heterogeneity in four families linked to chromosome 19p. Ann Neurol 1997, 41:8-16.

12. Jen JC, Graves TD, Hess EJ, Hanna MG, Griggs RC, Baloh RW; $\mathrm{CINCH}$ investigators: Primary episodic ataxias: diagnosis, pathogenesis and treatment. Brain 2007, 130:2484-93.

13. Ophoff RA, Terwindt GM, Vergouwe MN, van Eijk R, Oefner PJ, Hoffman SM, Lamerdin JE, Mohrenweiser HW, Bulman DE, Ferrari M, Haan J, Lindhout D, van Ommen G], Hofker MH, Ferrari MD, Frants RR: Familial hemiplegic migraine and episodic ataxia type- 2 are caused by mutations in the $\mathrm{Ca2}^{+}$channel gene CACNLIA4. Cell 1996, 87:543-52.

14. Denier C, Ducros A, Vahedi K, Joutel A, Thierry P, Ritz A, Castelnovo G, Deonna T, Gérard P, Devoize JL, Gayou A, Perrouty B, Soisson T, Autret A, Warter JM, Vighetto A, Van Bogaert P, Alamowitch S, Roullet E, Tournier-Lasserve E: High prevalence of CACNAIA truncations and broader clinical spectrum in episodic ataxia type 2. Neurology 1999, 52:1816-21. 
15. Mantuano E, Veneziano L, Spadaro M, Giunti P, Guida S, Leggio MG, Verriello L, Wood N, Jodice C, Frontali M: Clusters of nontruncating mutations of $\mathrm{P} / \mathrm{Q}$ type $\mathrm{Ca2}^{+}$channel subunit $\mathrm{Ca}(\mathrm{v})$ 2.1 causing episodic ataxia 2. J Med Genet 2004, 41:e82.

16. Shakkottai VG, Paulson HL: Physiologic alterations in ataxia: channeling changes into novel therapies. Arch Neurol 2009, 66:1196-201.

17. Browne DL, Gancher ST, Nutt JG, Brunt ER, Smith EA, Kramer P, Litt M: Episodic ataxia/myokymia syndrome is associated with point mutations in the human potassium channel gene, KCNAI. Nat Genet 1994, 8:136-40.

18. Litt M, Kramer P, Browne D, Gancher S, Brunt ER, Root D, Phromchotikul T, Dubay C], Nutt J: A gene for episodic ataxial myokymia maps to chromosome I2p I3. Am J Hum Genet 1994, 55:702-9.

19. Eunson LH, Rea R, Zuberi SM, Youroukos S, Panayiotopoulos CP, Liguori R, Avoni P, McWilliam RC, Stephenson JB, Hanna MG, Kullmann DM, Spauschus A: Clinical, genetic, and expression studies of mutations in the potassium channel gene KCNAI reveal new phenotypic variability. Ann Neurol 2000, 48:647-56.

20. Rajakulendran S, Schorge S, Kullmann DM, Hanna MG: Episodic ataxia type I: a neuronal potassium channelopathy. Neurotherapeutics 2007, 4:258-66.

21. Escayg A, De Waard M, Lee DD, Bichet D, Wolf P, Mayer T, Johnston J, Baloh R, Sander T, Meisler MH: Coding and noncoding variation of the human calcium-channel beta4-subunit gene CACNB4 in patients with idiopathic generalized epilepsy and episodic ataxia. Am J Hum Genet 2000, 66: I53I-9.

22. Guida S, Trettel F, Pagnutti S, Mantuano E, Tottene A, Veneziano L, Fellin T, Spadaro M, Stauderman K, Williams M, Volsen S, Ophoff R, Frants R, Jodice C, Frontali M, Pietrobon D: Complete loss of P/Q calcium channel activity caused by a CACNAIA missense mutation carried by patients with episodic ataxia type 2 . Am J Hum Genet 200I, 68:759-64.

23. Spacey SD, Hildebrand ME, Materek LA, Bird TD, Snutch TP: Functional implications of a novel EA2 mutation in the P/Qtype calcium channel. Ann Neurol 2004, 56:213-20.

24. Jeng CJ, Sun MC, Chen YW, Tang CY: Dominant-negative effects of episodic ataxia type 2 mutations involve disruption of membrane trafficking of human P/Q-type $\mathrm{Ca2}^{+}$channels. J Cell Physiol 2008, 21 4:422-33.

25. Zhuchenko O, Bailey J, Bonnen P, Ashizawa T, Stockton DW, Amos C, Dobyns WB, Subramony SH, Zoghbi HY, Lee CC: Autosomal dominant cerebellar ataxia (SCA6) associated with small polyglutamine expansions in the alpha IA-voltagedependent calcium channel. Nat Genet 1997, 15:62-9.

26. Matsuyama Z, Wakamori M, Mori Y, Kawakami H, Nakamura S, Imoto K: Direct alteration of the P/Q-type $\mathrm{Ca2}^{+}$channel property by polyglutamine expansion in spinocerebellar ataxia 6. J Neurosci 1999, 19:RCI4.

27. Restituito S, Thompson RM, Eliet J, Raike RS, Riedl M, Charnet P, Gomez CM: The polyglutamine expansion in spinocerebellar ataxia type 6 causes a beta subunit-specific enhanced activation of $P / Q$-type calcium channels in Xenopus oocytes. J Neurosci 2000, 20:6394-403.
28. Veneziano L, Guida S, Mantuano E, Bernard P, Tarantino P, Boccone L, Hisama FM, Carrera P, Jodice C, Frontali M: Newly characterised $\mathbf{5}^{\prime}$ and $3^{\prime}$ regions of CACNAIA gene harbour mutations associated with familial hemiplegic migraine and episodic ataxia. J Neurol Sci 2009, 276:31-7.

29. Riant F, Mourtada R, Saugier-Veber P, Tournier-Lasserve E: Large CACNAIA deletion in a family with episodic ataxia type 2 . Arch Neurol 2008, 65:817-20.

30. Labrum RW, Rajakulendran S, Graves TD, Eunson LH, Bevan R, Sweeney MG, Hammans SR, Tubridy N, Britton T, Carr LJ, Ostergaard JR, Kennedy CR, AI-Memar A, Kullmann DM, Schorge S, Temple K, Davis MB, Hanna MG: Large-scale calcium channel gene rearrangements in episodic ataxia and hemiplegic migraine: implications for diagnostic testing. J Med Genet 2009, 46:786-91.

3I. Graves TD, Imbrici P, Kors EE, Terwindt GM, Eunson LH, Frants RR, Haan J, Ferrari MD, Goadsby PJ, Hanna MG, van den Maagdenberg AM, Kullmann DM: Premature stop codons in a facilitating EF-hand splice variant of CaV2.I cause episodic ataxia type 2. Neurobiol Dis 2008, 32:10-5.

32. Watase $\mathrm{K}$, Barrett $\mathrm{CF}$, Miyazaki $\mathrm{T}$, Ishiguro $\mathrm{T}$, Ishikawa $\mathrm{K}, \mathrm{Hu} \mathrm{Y}$, Unno T, Sun Y, Kasai S, Watanabe M, Gomez CM, Mizusawa H, Tsien RW, Zoghbi HY: Spinocerebellar ataxia type 6 knockin mice develop a progressive neuronal dysfunction with agedependent accumulation of mutant CaV2.I channels. Proc Natl Acad Sci U S A 2008, 105: 1 1987-92.

FI000 Factor 3.0 Recommended Evaluated by Annette Dolphin 06 Oct 2008

33. Liu J, Tang TS, Tu H, Nelson O, Herndon E, Huynh DP, Pulst SM, Bezprozvanny I: Deranged calcium signaling and neurodegeneration in spinocerebellar ataxia type 2. J Neurosci 2009, 29:9148-62.

34. Heeroma JH, Henneberger C, Rajakulendran S, Hanna MG, Schorge S, Kullmann DM: Episodic ataxia type I mutations differentially affect neuronal excitability and transmitter release. Dis Model Mech 2009, 2:612-9.

35. Fletcher CF, Lutz CM, O'Sullivan TN, Shaughnessy JD Jr, Hawkes R, Frankel WN, Copeland NG, Jenkins NA: Absence epilepsy in tottering mutant mice is associated with calcium channel defects. Cell 1996, 87:607-17.

36. Mori Y, Wakamori M, Oda S, Fletcher CF, Sekiguchi N, Mori E, Copeland NG, Jenkins NA, Matsushita K, Matsuyama Z, Imoto K: Reduced voltage sensitivity of activation of $\mathrm{P} / \mathrm{Q}$-type $\mathrm{Ca2}^{+}$ channels is associated with the ataxic mouse mutation rolling Nagoya (tg(rol)). J Neurosci 2000, 20:5654-62.

37. Imbrici P, Jaffe SL, Eunson LH, Davies NP, Herd C, Robertson R, Kullmann DM, Hanna MG: Dysfunction of the brain calcium channel CaV2.I in absence epilepsy and episodic ataxia. Brain 2004, 127:2682-92.

38. Jouvenceau A, Eunson LH, Spauschus A, Ramesh V, Zuberi SM, Kullmann DM, Hanna MG: Human epilepsy associated with dysfunction of the brain P/Q-type calcium channel. Lancet 200I, 358:80I-7. 